\title{
Obituary of Professor Keith Vickerman FRS: Professor Keith Vickerman 1931-2016
}

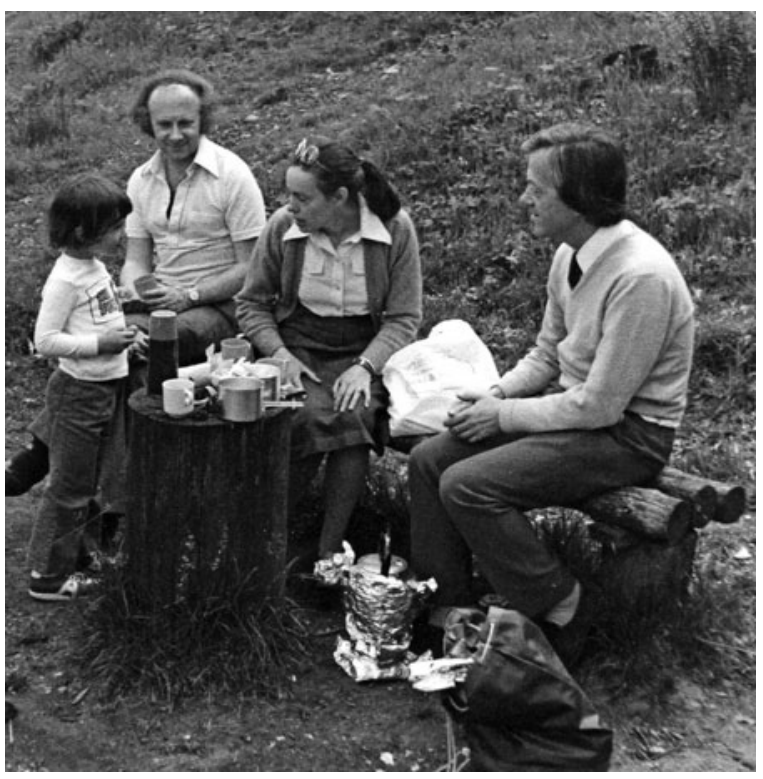

Figure 1. Keith Vickerman with his wife and daughter, with the author, in 1997

Professor Keith Vickerman, who died on June 28 2016, was a zoologist whose interests were primarily parasitic protozoa particularly trypanosomes. Keith, a Yorkshireman born in Huddersfield, Yorkshire, on March 21 1933, showed an interest in natural history from his earliest childhood days and was an avid collector of plants, animals and bones. His future was probably determined when he was about twelve years old when his parents bought him a brass microscope that became his favourite possession and which introduced him to the fascinating world of his hero Antoni van Leeuwenhoek's little animalcules. A little later his biology teacher at St James's School, Almondbury in Huddersfield showed him Paul de Kruiff's book The Microbe Hunters and the die was cast: thereafter all he wanted to do was to work with protozoa.

In 1952, with an enviable clutch of A levels, Keith left his native Yorkshire, never to return, and moved to London, which he later recalled was a terrifying experience, to read Zoology at University College London. Here his abilities were recognised by Professor P.B. Medawar, later Sir Peter Medawar and Nobel Laurate, who was to become his mentor. In his final year he studied parasitology as his special subject at King's College London under the guidance of a Lancastrian, the formidable helminthologist, Ben Dawes, who tried, unsuccessfully, to persuade him to work on parasitic worms because he did not think that there was anything in protozoology that was worth studying. However during this course he saw living trypanosomes in the blood of rats and later recalled how fascinated he was with their movements between red blood cells. Keith graduated with a London first class honours degree in 1955.

In 1955, at Medawar's suggestion, he moved to the University College of the South West (then an external college of the University of London before it became the University of Exeter in 1956) under the supervision of Dr Julian Hawes. His $\mathrm{PhD}$ project was concerned with the study of protozoan parasites of leatherjackets, the larvae of crane flies, which he extracted from the soil using a powerful disinfectant, Jeyes fluid - much to the annoyance of the groundsmen. He wrote up only part of his comprehensive thesis, a description of a kinetoplastid flagellate Herpetamonas lugwig, for his first paper in Parasitology. During his postgraduate tenureship Hawes became indisposed and Keith, who was also employed as a demonstrator, took over his teaching duties. This was an experience that was to serve him well when, in 1958, he was awarded a Wellcome Trust funded lectureship back in the Department of Zoology at University College. Keith's interest in microscopy led him inevitably to the relatively new science of electron microscopy. At that time the Anatomy Department at University College possessed one of the few electron microscopes in London and there he developed the skills necessary to become an expert in electromicroscopy. Keith prepared his own materials, made his own glass knives and did everything from fixing his material to taking, developing and printing his electron micrographs. His first papers were on the fine structure of Acanthamoeba and Limax amoebae, but he chose to study African trypanosomes that he had seen as a student and were large and easily available. At first his interests centred on the morphology of trypanosomes, particularly the flagellum and its mode of attachment to the body of the cell and he produced some superb electronmicrographs that set a standard seldom surpassed.

At the end of his five-year tenure at University College, in 1963, Keith was awarded a Royal Society's Tropical Research Fellowship that 
enabled him to work on the life cycles of the pathogenic trypanosomes of humans and domestic animals and to work closer to the field. Keith had been slightly worried that the trypanosomes he had been using might have lost something during their long passage in laboratory animals so he needed some material fresh from the field. He had already worked at the East African Trypanosomiasis Research Organization in Tororo, Uganda, in 1960. In 1964 he decided to expand his experience and spent some time at the Nigerian Institute of Trypanosomiasis Research in Jos, in northern Nigeria. On both occasions he had access to a plentiful supply of the fresh material he needed, some of which he worked with on site and some of which he brought back to the UK. Using a combination of light microscopy, electronmicroscopy and cytochemistry, he discovered that trypanosomes possess a single mitochondrion that is activated differently in the dividing forms in the blood and in the nondividing forms infective to tsetse flies. He then demonstrated that the metabolism of the dividing forms in the blood, where there are ample supplies of carbohydrate substrate and oxygen, is essentially aerobic while in the tsetse fly, where these resources are lacking, it is anaerobic. His results were published in a modest paper in Nature in1965. These studies essentially completed our knowledge of the life cycle of African trypanosomes begun by Muriel Robertson in the 1910s and abandoned on the outbreak of the Second Word War. By the mid-1960s Muriel Robertson was in her 80's but shared Keith's delight in his discoveries. Although not their primary aim, these discoveries are directly relevant to the development of much needed antitrypanosome drugs

In 1968 Keith moved from London to the University of Glasgow where he continued his studies on trypanosomes, particularly the fine structure of the flagellum and surface, and this led to his next major discovery. Ronald Ross, the discoverer of mosquito transmission of malaria had, in 1909, noticed that the populations of trypanosomes in the blood of humans came in waves that disappeared and re-emerged later and that this pattern of events went on indefinitely. Keith decided to look at this problem and, working with Matt Cunningham in Tororo, he had begun to look at the agglutination of trypanosomes in immune sera. This did not lead him anywhere as he had little interest in immunology, so he decided to investigate this further at the electronmicroscopical level and found that the trypanosome surface consisted of a fuzzy coat that had seen by others but dismissed as artefacts. Keith believed that this structure was real and must, therefore, have a function. He discovered that this surface coat consisted of a dominant surface coat antigen recognised by the immune system. He further showed that when trypanosomes were recognised they were destroyed, while at the same time another population of trypanosomes expressing a different variant of the surface coat was emerging. They became dominant until, in their turn, they were also eliminated: this process could go on indefinitely, a phenomenon called antigenic variation. This phenomenon had been known for viruses and bacteria but never before for a eukaryotic cell and has now been shown to apply to other protozoa including free-living flagellates, soil amoebae, malaria parasites, leishmanias and Giardia spp. The immediate impact of these discoveries was the realisation that there could not be a conventional vaccine. Keith could never have imagined that his discovery would result in what can only be called a growth industry among biochemists, molecular biologists and geneticists, who have probed the phenomenon of antigenic variation in trypanosomes in the minutest detail and has resulted in the publication of dozens of papers every year. Reference to antigenic variation on any database or website will bring up more hits for trypanosomes than any other examples.

In 1974, Keith was appointed to a titular chair in the Department of Zoology at Glasgow University. In 1979 he was appointed John Graham Kerr Professor of Zoology and in 1984 Regius Professor. His teaching load at Glasgow, even as a professor, was very heavy and he was particularly interested in maintaining the interest of the large numbers of first year students by continually devising new courses such as including one on animal domestication.

Keith was, however, able to continue his research on trypanosomes until 1993 when he turned his attention to the study of soil flagellates, cultures of which he maintained himself and, after his retirement in 2000, began a series of collaborative studies with Tom Cavalier-Smith on the phylogeny and classification of flagellates. He never tried to build up a large team of researchers nor to apply for major grants but was quite happy to work with small numbers of postgraduate students and research colleagues.

Keith played an important role in establishing parasitology and protozoology in Britain. He was a founder member of the British Society for Parasitology and an Honorary Member and a founder member of the British Section of the Society of Protozoologists. When he was in London, he regularly took part in meetings of the Royal Society of Tropical Medicine and Hygiene. $\mathrm{He}$ was in great demand as an external examiner for both undergraduate and postgraduate degrees.

Keith's achievements were recognised by the award of numerous prestigious honours, Fellowship of the Royal Society of Edinburgh, Fellowship of the Royal Society of London and Fellowship of the Academy of Medical Sciences (of which he was a founder member), and was the recipient the Royal 
Society Leeuwenhoek medal and the gold medal of the Linnean Society. He was regularly invited to give plenary lectures at national and international congresses and was very conscientious in his preparation: he never repeated a lecture.

Keith had an association with Parasitology lasting nearly 40 years. He was on the panel of referees from 1973 to 1979 and a member of the Advisory, later the Editorial Board, of Parasitology from 1979 to 2010. We, as Editors, always relied on him to provide honest and helpful referee reports, particularly with difficult papers, of which he was sent an excessive number in the knowledge that he would give a reasoned judgement which was accepted by and helpful to the authors. Many parasitologists have good reason to be grateful for the improvements that he made to their manuscripts. Even when he recommended rejection it was done in a kindly and helpful way.
Keith Vickerman was a keen gardener and maintained a very productive and interesting allotment. He was President of the Friends of the Glasgow Botanic Gardens and successfully fought off plans for an unsuitable building on the site. He also addressed the Scottish Parliament on the need for allotments and green corridors running through cities.

In 1961 Keith married Moira Dutton, who he met at Exeter. She survives him with their adopted daughter, the harpist Louise Vickerman.

Professor Keith Vickerman, born March 21 1933, died June 28, 2016.

Obituary written by his friend, Professor Frank Cox, a previous Editor of Parasitology.

FRANCIS COX 